\title{
Platelet PAR1 receptor density-Correlation to platelet activation response and changes in exposure after platelet activation
}

\author{
Sofia Ramström, Karin Vretenbrant-Öberg, Finn Åkerström, \\ Camilla Enström and Tomas Lindahl
}

\section{Linköping University Post Print}

\begin{abstract}
N.B.: When citing this work, cite the original article.
\end{abstract}
Original Publication:

Sofia Ramström, Karin Vretenbrant-Öberg, Finn Åkerström, Camilla Enström and Tomas Lindahl, Platelet PAR1 receptor density-Correlation to platelet activation response and changes in exposure after platelet activation, 2008, Thrombosis Research, (121), 5, 681-688. http://dx.doi.org/10.1016/j.thromres.2007.06.010

Copyright: Elsevier http://www.elsevier.com/

Postprint available at: Linköping University Electronic Press http://urn.kb.se/resolve?urn=urn:nbn:se:liu:diva-43417 


\section{Regular Article:}

Platelet PAR1 receptor density - correlation to platelet activation response and changes in exposure after platelet activation

Sofia Ramström ${ }^{1}$, Karin Vretenbrant Öberg ${ }^{1}$, Finn Åkerström ${ }^{2}$, Camilla Enström ${ }^{3}$, Tomas L Lindahl ${ }^{1,3}$

1. Department of Biomedicine and Surgery, Division of Clinical Chemistry, University Hospital, SE-581 85 Linköping, Sweden.

2. Leicester Medical School, University of Leicester, UK.

3. Department of Clinical Chemistry, Laboratory Medicine, University Hospital, Linköping, Sweden.

Word count: 4919

Corresponding author: Sofia Ramström

Address: Dept. of Biomedicine and Surgery, Div. of Clinical Chemistry, University Hospital, SE-581 85 Linköping, Sweden

Telephone: +4613222425

Fax number: +46 13223240

E-mail: sofra@ibk.liu.se

Some of the data in this manuscript was presented as oral presentations at the 8th UK Platelet Meeting in Reading, UK, on the $7^{\text {th }}$ of September, 2006 and at "ADP 2006", the $4^{\text {th }}$ International Meeting on Platelet P2 receptors in Bischoffsheim, France, on the $5^{\text {th }}$ of October, 2006. 


\section{Abstract:}

Introduction: A polymorphism (-14 A/T) affecting PAR1 expression on the platelet surface has recently been identified. A two-fold variation in receptor density, which correlated with the platelet response to PAR1-activating peptide (PAR1-AP), has been reported.

Materials and methods: We used flow cytometry to measure the correlation between the number of PAR1 receptors and platelet activation. We also measured the changes in receptor exposure after platelet activation with PAR1-AP, ADP, PAR4-AP or a collagen-related peptide (CRP).

Results: In our study, the PAR1 receptor number varied almost four-fold, from 547 to 2063 copies/platelet (mean \pm S.D. $1276 \pm 320, n=70)$.

The number of PAR1 receptors on resting platelets correlated to platelet fibrinogen binding and P-selectin expression following platelet activation with PAR1-AP $\left(\mathrm{r}^{2}=0.30, \mathrm{p}<0.01\right.$ and $r^{2}=0.15, p<0.05$, respectively, $\left.n=36\right)$. The correlation was not improved by exclusion of the ADP-component from the PAR1-AP induced response.

We found a trend, but no statistically significant differences in PAR1 receptor number and platelet reactivity between $\mathrm{A} / \mathrm{A}$ individuals and T/A or T/T individuals.

Ex vivo activation with PAR1-AP decreased PAR1 surface exposure to $71 \pm 19 \%$ of the exposure on resting platelets (mean \pm S.D., $\mathrm{p}<0.01, \mathrm{n}=19$ ), while activation by ADP, PAR4-AP or CRP significantly increased the exposure, to $151 \pm 27 \%, 120 \pm 21 \%$ and $138 \pm 25 \%$, respectively ( $\mathrm{n}=11,11$ and 10$)$.

Conclusions: This study shows a large variation in PAR1 receptor number in healthy individuals, a variation correlated to the platelet activation response. We found a significant reduction in PAR1 surface exposure after adding PAR1-AP, while activation with ADP, PAR4-AP or CRP increased the exposure. 
Keywords: hemostasis, flow cytometry, platelet activation, Protease-Activated Receptor 1,

PAR1 receptor

Abbreviations

\begin{tabular}{|c|c|}
\hline ADP & Adenosine diphosphate \\
\hline CRP & $\begin{array}{l}\text { Collagen-related peptide, sequence GCO-(GPO) }{ }_{10}-\mathrm{GCOG}_{-} \mathrm{NH}_{2} \text {, } \\
\text { where } \mathrm{O} \text { is hydroxyproline }\end{array}$ \\
\hline EDTA & Ethylenediaminetetraacetic acid \\
\hline FITC & Fluorescein \\
\hline $\mathrm{GPIb}_{\alpha}$ & Glycoprotein $\mathrm{Ib}_{\alpha}$ \\
\hline MPV & Mean platelet volume \\
\hline MRS2179 & $\begin{array}{l}\text { Antagonist to the platelet } \mathrm{P} 2 \mathrm{Y}_{1} \text { receptor; } \mathrm{N}^{6} \text {-methyl-2'- } \\
\text { deoxyadenosine-3',5'-bisphosphate }\end{array}$ \\
\hline $\mathrm{P} 2 \mathrm{Y}_{1}$ & Platelet ADP receptor $\mathrm{P} 2 \mathrm{Y}_{1}$ \\
\hline $\mathrm{P}_{2} \mathrm{Y}_{12}$ & Platelet ADP receptor $\mathrm{P}_{2} \mathrm{Y}_{12}$ \\
\hline PAR1, PAR4 & $\begin{array}{l}\text { Protease-activated receptor } 1 \text {, protease-activated receptor } 4 \text {, } \\
\text { platelet receptors for thrombin }\end{array}$ \\
\hline PAR1-AP & PAR1 receptor activating peptide, amino acid sequence SFLLRN \\
\hline PAR4-AP & PAR4 receptor activating peptide, amino acid sequence AYPGKF \\
\hline PCR & Polymerase chain reaction \\
\hline SNP & Single nucleotide polymorphism \\
\hline
\end{tabular}




\section{Introduction}

Thrombin, formed in the coagulation cascade, is a strong platelet activator. There are at least three receptors for thrombin on human platelets, PAR1, PAR4 and GPIb $\alpha$. Both PARs belong to the seven transmembrane family of G-protein linked receptors and have been cloned and sequenced. Both are coupled to $\mathrm{G} \alpha \mathrm{q}$ and $\mathrm{G} \alpha_{12 / 13}[1]$. Thrombin cleaves the receptors within the large N-terminal extracellular domain, creating new amino terminals, SFLLRN and GYPGQV respectively $[2,3]$. The new $\mathrm{N}$-terminus formed by thrombin cleavage serves as a “tethered ligand" [4] which binds intramolecularly and causes receptor activation. Specific agonist peptides, mimicking the new $\mathrm{N}$-terminus, have been designed, for PAR1 the most often used is SFLLRN (PAR1-AP) [5], for PAR4 the most potent is AYPGKF (PAR4-AP) [6]. If both cleavage sites are blocked by antibodies raised against peptides spanning the cleavage sites, the platelet response to thrombin is abolished [7]. It is known that, like other G protein-coupled receptors, PAR1 is quickly uncoupled from signalling and internalised, by sequestration into endosomes via coated pits, after activation by PAR1-AP [8]. In addition, there is some evidence that an additional way of PAR1 downregulation could occur by shedding into microparticles along with other integral membrane proteins [9].

A polymorphism (-14 A/T) that affects PAR1 expression on the platelet surface has recently been identified. It has earlier been reported by Dupont et al. [10] that healthy volunteers showed a two-fold variation in receptor density which correlated with the exposure of platelet P-selectin and the aggregatory response induced by addition of PAR1-AP.

In this study we have used flow cytometry to measure the correlation between the number of PAR1 receptors per platelet and PAR1-AP induced platelet activation. In a portion of the samples, the number of PAR1 receptors was also measured after platelet activation with PAR1-AP, ADP, PAR4-AP or a collagen related peptide (CRP) to examine a possible decrease in receptor number indicating internalisation. We have also used ADP receptor 
antagonists in order to remove the ADP-dependent part of the PAR1 response and examine whether this would improve the correlation between PAR1 receptor number and PAR1-AP induced platelet activation.

\section{Materials and methods}

\section{Blood sampling}

Venous blood was collected with minimal trauma from healthy adult volunteers donating blood at the local blood centre and from laboratory staff. In total there were 34 different female and 36 different male donors included. The age distribution was $44.6 \pm 13.5$ years and $40.6 \pm 12.4$ years, respectively. The blood donors were apparently healthy individuals, who had not ingested any drugs known to interfere with platelet function and without reported bleeding problems. They were informed about the purpose of the study and gave informed consent. The blood collection protocol was approved by the Ethics Committee at Linköping University Hospital.

Blood was collected by venipuncture and collected into $4.5 \mathrm{~mL}$ plastic vacuum tubes, $\mathrm{S}$ Monovette $^{\circledR}$ (Sarstedt, Nümbrecht, Germany) or Vacutainer ${ }^{\circledR}$ (Becton Dickinson, Franklin Lakes, NJ, USA) containing sodium citrate (final concentration $13 \mathrm{mmol} / \mathrm{L}$ ). The blood was then kept at room temperature for a minimum of 30 minutes and maximum of 2 hours before use in any of the two studies. A sample tube with EDTA as anticoagulant (Vacutainer ${ }^{\circledR}$ ) was also collected for the determination of mean platelet volume, utilising the Cell-Dyn 4000 analysis system (Abbot Laboratories, Abbott Park, Illinois, USA).

\section{Reagents}

Chemicals used for the HEPES buffer $(137 \mathrm{mmol} / \mathrm{L} \mathrm{NaCl}, 2.7 \mathrm{mmol} / \mathrm{L} \mathrm{KCl}, 1 \mathrm{mmol} / \mathrm{L}$ $\mathrm{MgCl}_{2}, 5.6 \mathrm{mmol} / \mathrm{L}$ glucose, $1 \mathrm{~g} / \mathrm{L}$ bovine serum albumin and $20 \mathrm{mmol} / \mathrm{L}$ HEPES (N-[2- 
hydroxyethyl]piperazine-N'-[2-ethanesulphonic acid]), $\mathrm{pH}$ 7.40) was from Sigma Chemical Company (St. Louis, MO, USA). Recombinant hirudin (lepirudin, Refludan ${ }^{\circledR}$ ) was from Aventis (Strasbourg, France). The platelet fibrinogen receptor antagonist Ro 44-9883 (lamifiban) was kindly provided by F. Hoffmann la Roche Ltd (Basel, Switzerland). The P2 $Y_{1}$ ADP-receptor antagonist MRS2179 ( $\mathrm{N}^{6}$-methyl-2'-deoxyadenosine-3',5'-bisphosphate) (tetraammonium salt) was from Tocris Cookson Ltd (Bristol, UK), and was dissolved in distilled water to a concentration of $10 \mathrm{mmol} / \mathrm{L}$. The P2Y ${ }_{12}$ ADP-receptor antagonist cangrelor ( $\mathrm{N}^{6}$-(2-methyl-tioethyl)-2-(3,3,3-trifluoropropylthio)- $\beta$, $\gamma$-dichloromethylene ATP) (tetrasodium salt), formerly designated as AR-C69931MX, was kindly provided by The Medicines Company (New Jersey, USA). It was dissolved in $0.9 \% \mathrm{NaCl}$ to a concentration of $10 \mathrm{mmol} / \mathrm{L}$

The platelet calibrator kit (Platelet Calibrator, Biocytex, Marseille, France) included a mixture of 4 calibration beads coated with increasing concentrations of mouse IgGs $(490,13000,38$ 000 and 90 000), a secondary polyclonal antimouse IgG-fluorescein isothiocyanate (FITC) antibody used as a staining reagent, a negative isotypic control $\operatorname{IgG}_{1}$ and a buffer. The antiPAR1 (WEDE15) and anti-GPIb (SZ2) IgG 1 mouse antibodies and the FITC-conjugated mouse antibody against human P-selectin were purchased from Immunotech (Marseilles, France). The anti-PAR1 antibody is directed towards amino acids 51-64 of the PAR1 Nterminus and thus targets both cleaved and uncleaved receptors. The FITC-conjugated chicken antibody towards human fibrinogen was purchased from Diapensia HB (Linköping, Sweden). The FITC-conjugated irrelevant mouse $\operatorname{IgG}_{1}$ antibody was purchased from Dako AS (Glostrup, Denmark).

Thrombin PAR1 receptor activating peptide (PAR1-AP, sometimes denoted TRAP), sequence SFLLRN, and PAR4-AP, sequence AYPGKF, were both purchased from the Biotechnology Centre of Oslo, Oslo University, Norway. The peptides were dissolved in $0.9 \% \mathrm{NaCl}$ to 3.7 
$\mathrm{mM}$ (PAR1-AP) or $10 \mathrm{mM}$ (PAR4-AP). For some experiments, the PAR1-AP solution was further diluted to $75 \mu \mathrm{M}$ in HEPES buffer. ADP was purchased from Sigma Chemicals Co (St. Louis, MO, USA) and diluted in $0.9 \% \mathrm{NaCl}$ to $8.5 \mu \mathrm{mol} / \mathrm{L}$. The collagen-related peptide (CRP) with the sequence Gly-Cys-Hyp-(Gly-Pro-Hyp) ${ }_{10}$-Gly-Cys-Hyp-Gly- $\mathrm{NH}_{2}$ was kindly provided by Dr. Richard W. Farndale and Dr. Graham Knight, Cambridge, UK and crosslinked with SPDP (3-(2-pyridyldithio)propionic acid N-hydroxysuccinimide ester) according to their instructions [11]. The peptide solution was diluted to $55 \mu \mathrm{g} / \mathrm{mL}$ in $0.05 \%$ acetic acid and further diluted 1:4 in HEPES buffer upon thawing.

The antibodies were kept at $+8^{\circ} \mathrm{C}$. All other solutions were portioned, kept at $-70^{\circ} \mathrm{C}$ and thawed in a water bath just before use.

\section{Flow cytometry}

Flow cytometry was performed on a Coulter Epics XL.MCL flow cytometer with Expo 32 ADC software from Beckman Coulter, Miami, USA. Fluorosphere control samples (FlowCheck $^{\mathrm{TM}}$ and Flow-Set ${ }^{\mathrm{TM}}$ ) from the same supplier were analysed every day to verify that instrument optical alignment, fluidics and fluorescence intensity readings were stable over time.

\section{Measurements of fibrinogen binding and P-selectin exposure}

Whole blood $(10 \mu \mathrm{L})$ was incubated with FITC-conjugated anti-fibrinogen antibodies (2 $\mu \mathrm{g} / \mathrm{mL}$ final concentration $)$ or FITC-conjugated anti-P-selectin $(0.24 \mu \mathrm{g} / \mathrm{mL}$ final concentration) and HEPES buffer to a total volume of $130 \mu \mathrm{L}$. After 10 minutes PAR1-AP was added (final concentration $5 \mu \mathrm{mol} / \mathrm{L}$ ). For experiments with ADP-receptor antagonists, portions of whole blood were pre-incubated for 10 minutes with $200 \mu \mathrm{mol} / \mathrm{L}$ MRS2179, 100 $\mu \mathrm{mol} / \mathrm{L}$ cangrelor, or a combination of both antagonists before the start of the experiments. In these experiments, a higher concentration of PAR1-AP (final concentration $75 \mu \mathrm{mol} / \mathrm{L}$ ) was 
used, at lower concentrations the PAR1-AP induced response was totally abolished. The reaction was stopped after exactly 10 minutes by the addition of 1 mL HEPES buffer. The sample was subsequently diluted 1:5 in HEPES buffer before analysis on the flow cytometer. The platelet population was identified by its light scattering properties (forward vs. side scatter). Platelet activation was detected as \% FITC-positive cells, using either FITCconjugated fibrinogen or P-selectin antibodies. A cut-off was set in the FITC fluorescence channel to divide a platelet population containing non-binding antibody with corresponding fluorescence intensity into two fractions, one that contained $98.5-99.5 \%$ of the platelets and the other containing the brightest $0.5-1.5 \%$ of the platelets. Platelets with fluorescence intensity higher than the pre-set cut-off were identified as fibrinogen binding or P-selectin positive cells, respectively. For all samples, the mean fluorescence intensity (MFI) for the whole platelet population was also determined. Control samples, lacking PAR1-AP, were prepared from each donor to ensure the absence of pre-activated platelets. All samples were run in duplicate.

\section{Measurements of PAR1 receptor number}

In the second experiment, whole blood was diluted (1:4) with the buffer provided in the Platelet Calibrator kit. The diluted blood $(10 \mu \mathrm{L})$ was then incubated with $10 \mu \mathrm{L}$ of anti-PAR1 or anti-GPIb $\mathrm{IgG}_{1}$ mouse antibody (final concentration $5 \mu \mathrm{g} / \mathrm{mL}$ ) or the same concentration and volume of an irrelevant mouse $\mathrm{IgG}_{1}$ antibody (isotypic control). After 10 minutes of incubation, a FITC-labelled secondary polyclonal anti-mouse IgG antibody $(10 \mu \mathrm{L})$ was added and after an additional 10 minutes of incubation the mixture was diluted with $1 \mathrm{~mL}$ of the buffer provided with the kit. Calibration beads $(20 \mu \mathrm{L})$ were also stained with the secondary antibody and then diluted with $1 \mathrm{~mL}$ of buffer. All steps were performed according to the manufacturer's instructions. The sample tubes were stored in the dark and analysed with flow cytometry for mean fluorescence intensity (MFI) within 2 hours. On every occasion a 
calibration curve, based on the MFI and the known number of antigen sites for the calibration beads, was elicited for each sample series. By using the calibration curve, the number of specific PAR1 receptors could be obtained by subtracting the total number of the anti-PAR1 WEDE15 antibody binding sites with the negative isotypic control. To reduce the errors caused by imprecision in the reading of the fluorescence of the calibration beads, we chose to read all samples with the same calibration curve, where the fluorescence values were a mean of 24 measurements performed during the time of the study (the coefficient of variation $(\mathrm{CV})$ for the different beads were 7.6, 7.0, 6.0 and 5.8\%, respectively). A number of samples were also prepared with whole blood, previously activated with ADP $(4.25 \mu \mathrm{mol} / \mathrm{L}), \mathrm{PAR} 1-\mathrm{AP}$ (37 $\mu \mathrm{mol} / \mathrm{L})$, PAR4-AP ( $5 \mathrm{mmol} / \mathrm{L})$ or CRP $(6.9 \mu \mathrm{g} / \mathrm{mL})$ for 10 minutes. Blood samples from some individuals were activated both in the absence and presence of Ro 44-9883 (final concentration $0.1 \mu \mathrm{M}$ ) or recombinant hirudin (final concentration $200 \mathrm{ATU} / \mathrm{mL}$ ) to check for eventual platelet aggregation or thrombin formation in the original experimental setup. As an additional test for platelet aggregation, the time needed for detection of 5000 single platelets during the flow cytometry analysis was also recorded for all samples analysed. All experiments were performed at room temperature and without stirring. All samples were run in duplicate.

\section{Genotyping of IVSn-14 A/T}

\section{PCR}

DNA was extracted from samples of EDTA blood on GenoVision 48 (BioRobot ${ }^{\circledR}$ M48, Qiagen, Hilden, Germany) by using the MagAttract DNA Blood Mini M48 Kit (Qiagen, Hilden, Germany) according to the manufacturer's instructions. A fragment of 155 base pairs encompassing the IVSn-14 A/T SNP was amplified with polymerase chain reaction (PCR). The PCR was performed in $20 \mu \mathrm{L}$ reactions, in a Mastercycler ${ }^{\circledR}$ ep gradient $\mathrm{S}$ (Eppendorf AG, 
Hamburg, Germany). Each sample consisted of $1 \mathrm{X}$ PCR buffer with $1.5 \mathrm{mM} \mathrm{MgCl}$ (Qiagen, Hilden, Germany), $0.5 \mathrm{mM} \mathrm{MgCl} 2$ (Qiagen, Hilden, Germany), $0.2 \mathrm{mM}$ deoxyribonucleoside triphosphate (dNTP) (ABgene, Epsom, UK), nuclease-free water (Sigma- Aldrich, Buchs, Switzerland), 20 pmol of each primer (forward: 5'-TTG TCG CTT TTG CCT TGT T-3', reverse: 5'-TCA TCC TCC CAA AAT GGT TC-3') (Invitrogen, Carlsbad, USA), and 0.5 units HotStar Taq ${ }^{\circledR}$ DNA Polymerase (Qiagen, Hilden, Germany). The amount of template DNA used for the PCR was approximately $20 \mathrm{ng}$. The PCR conditions after initial hot start activation at $95{ }^{\circ} \mathrm{C}$ for 15 min were as follows; 35 cycles consisting of denaturation at $95{ }^{\circ} \mathrm{C}$ for $30 \mathrm{~s}$, annealing at $57{ }^{\circ} \mathrm{C}$ for $30 \mathrm{~s}$ and extension at $72{ }^{\circ} \mathrm{C}$ for $50 \mathrm{~s}$, and a final extension step at $72{ }^{\circ} \mathrm{C}$ for $5 \mathrm{~min}$.

\section{DHPLC}

Genotyping of the IVSn-14 A/T SNP was performed on an automated denaturing high performance liquid chromatography (DHPLC) analysis system (Transgenomic Inc, Omaha, USA). The PCR products were denatured at $95{ }^{\circ} \mathrm{C}$ for 1 min and $94{ }^{\circ} \mathrm{C}$ for 3 min and the temperature was gradually lowered to $24{ }^{\circ} \mathrm{C}$ at a rate of $1.5^{\circ} \mathrm{C} / \mathrm{min}$, during which the fragments reannealed. A mixture of hetero- and homoduplexes was then formed in individuals that were heterozygous for the SNP. The samples $(5 \mu \mathrm{L})$ were injected onto a DNA Sep HT Column (Transgenomic Inc, Omaha, USA), and run at $55.3{ }^{\circ} \mathrm{C}$. Elution of the DNA was performed with a linear acetonitrile gradient $(0.1 \mathrm{M}$ triethylammonium acetate (TEAA) /0.1 M TEAA with $25 \%$ acetonitrile). Hetero- and homoduplexes were detected by UVabsorbance at $260 \mathrm{~nm}$. Detection of homozygous mutants was carried out by mixing samples with a known wild type sample in a 1:1 ratio to induce heteroduplex formation. The mixture was heated and allowed to reanneal in a step down protocol, and injected onto the column again. 


\section{Statistics}

Comparisons between groups were made using non-parametric tests, Wilcoxon Signed Ranks test (paired data) or Mann Whitney U Test (unpaired data). The correlations between receptor numbers and platelet activation responses or MPV were investigated using bivariate correlation analysis to calculate the Pearson correlation coefficients. The two-tailed significance of the correlations was also calculated. Data analysis was performed using SPSS for Windows (SPSS Inc., Chicago, IL, USA).

\section{Results}

Due to the fact that our initial trials indicated that there were considerable variations between duplicate samples, we performed all our measurements in duplicate. We found that the CV's for the imprecision within the duplicate samples were $25.7 \%$ for the negative control and $11.1 \%$ for the samples with the PAR1 antibody $(n=75)$.

The PAR1 receptor number on resting platelets ranged from 547 to 2063 copies/platelet in the population examined (mean \pm S.D. $1276 \pm 320, \mathrm{n}=70$ ). The number did not differ between male and female donors (1281 \pm 278 in male and $1270 \pm 364$ in female donors, respectively). The mean platelet volume (MPV) was also determined and compared to the number of PAR1 receptors. There was a weak positive correlation between MPV and PAR1 receptor number, $\left(r^{2}=0.08, p<0.05, n=70\right)$ (see figure 1A). As a comparison, a much higher correlation between MPV and the number of GPIb receptors was observed when this was investigated in a part of the population studied $\left(\mathrm{r}^{2}=0.22, \mathrm{p}<0.05, \mathrm{n}=18\right)$ (figure $\left.1 \mathrm{~B}\right)$, but there was no significant correlation between PAR1 and GPIb receptor number (data not shown). Also, there were no significant correlations between MPV and PAR1-AP-induced fibrinogen 
binding or P-selectin expression (data not shown). The MPV did not differ between male and female donors $(8.1 \pm 1.0$ in male and $8.1 \pm 0.7$ in female donors, respectively).

We found a strong correlation between platelet-bound fibrinogen and P-selectin expression, after platelet activation with PAR1-AP (final concentration $5 \mu \mathrm{mol} / \mathrm{L}$ ) and the number of PAR1 receptors on resting platelets $\left(\mathrm{r}^{2}=0.30, \mathrm{p}<0.01, \mathrm{n}=36\right.$ and $\left.\mathrm{r}^{2}=0.15, \mathrm{p}<0.05, \mathrm{n}=36\right)$ (figures 2A and 2B). There were no significant differences in PAR1-AP induced activation responses between male and female donors (data not shown). In a part of the study, we activated samples with PAR1-AP $(75 \mu \mathrm{M})$ in the presence of ADP receptor antagonists in order to remove the ADP-dependent part of the PAR1 response; the aim was to see whether this could improve the correlation between PAR1 receptor number and PAR1-AP-induced platelet activation. The results from this are shown in table 1 . We found no improved correlations in the presence of ADP receptor antagonists. In control experiments, the concentrations of ADP antagonists used were shown to completely block platelet fibrinogen binding induced by $0.85 \mu \mathrm{M}$ ADP ( $\mathrm{n}=6$, data not shown).

We also studied how activation of the platelets affected the number of PAR1 receptors. We found a significant decrease in PAR1 receptor number when platelets were exposed to PAR1$\operatorname{AP}(37 \mu \mathrm{mol} / \mathrm{L})$, while activation with $\operatorname{ADP}(4.25 \mu \mathrm{mol} / \mathrm{L}), \mathrm{PAR} 4-\mathrm{AP}(5 \mathrm{mmol} / \mathrm{L})$ or $\mathrm{CRP}(6.9$ $\mu \mathrm{g} / \mathrm{mL}$ ) significantly increased the number of PAR1 receptors (figure 3). When the control with resting platelets from the same donor was set to $100 \%$, the mean receptor number after activation with PAR1-AP was $71 \pm 19 \%(\mathrm{n}=19)$, while activation with ADP, PAR4-AP and CRP gave mean receptor numbers of $151 \pm 27 \%, 120 \pm 21 \%$ and $138 \pm 25 \%$, respectively $(\mathrm{n}=$ 11, 11 and 10, respectively). We also performed a control experiment where the samples were activated in the presence of the thrombin inhibitor hirudin, to ensure that the results were not 
obscured by the formation of thrombin in the samples during activation. The PAR1 receptor numbers found in the presence and absence of hirudin did not differ for any of the platelet agonists (n=5-6, data not shown).

To check for eventual platelet aggregation during the activation of the samples, we also recorded the time needed for the analysis of 5000 platelets in the flow cytometer. When the time for the control with resting platelets from the same donor was set to $100 \%$, the mean time for 5000 particles after activation with PAR1-AP was $113 \pm 16 \%(n=11)$, while activation with ADP, PAR4-AP and CRP gave mean times for 5000 particles of $112 \pm 11 \%$, $97 \pm 16 \%$ and $124 \pm 17 \%$, respectively ( $\mathrm{n}=11,11$ and 10 , respectively). We also performed some control experiments in the presence of the fibrinogen receptor antagonist Ro 44-9883 to prevent the formation of platelet aggregates during the activation procedure. We found that even though the presence of Ro 44-9883 significantly decreased the time to count 5000 particles in samples with PAR1-AP, ADP and CRP $(98 \pm 6 \%, 102 \pm 4 \%$ and $103 \pm 7 \%$, respectively, $\mathrm{p}<0.05, \mathrm{n}=5$ ), this had small effect on the number of PAR1 receptors found in the samples. The only significant change was with ADP as activator, where the PAR1 receptor number was $1953 \pm 283$ in the absence and $1510 \pm 238$ in the presence of Ro 44$9883(\mathrm{p}<0.05, \mathrm{n}=5)$.

67 of the individuals examined were also genotyped for the know polymorphism in the intervening sequence (IVSn)- 14A/T, that has been previously coupled to PAR1 receptor expression [10] and increased response to PAR1-AP [10, 12]. In this material, we found 47 A/A homozygotes (70\%), 18 A/T heterozygotes (27\%) and 2 T/T homozygotes (3\%). Figure 4 shows the distribution in PAR1 receptor number for the different genotypes. We also grouped the individuals into quartiles with regard to their platelet activation response (defined 
as percentage anti-fibrinogen binding platelets in response to PAR1-AP stimulation). This allowed us to group individuals even though they had been analysed using two different concentrations of PAR1-AP. The results are shown in figure 5. Due to the difference in the number of individuals, we chose to group individuals with at least one T-allele into one group for the statistical analysis. However, there were no statistically significant differences in PAR1 receptor number or platelet reactivity between A/A individuals and the T/A or T/T individuals.

\section{Discussion}

In the population examined in this study, we found PAR1 receptor numbers ranging from 547 to 2063 with a mean of 1276 copies/platelet. This mean value was similar to that reported by Dupont et al. [10], who used the same methods and reagents. However, the same authors found only a 2 -fold variability in the PAR 1 receptor number. A previous study with ${ }^{125} \mathrm{I}$ thrombin found that there are approximately 50 high affinity binding sites/platelet and 1700 moderate affinity sites per platelet [13]. In subsequent experiments utilising radioiodinated monoclonal antibodies, directed towards the C-terminal of the cleavage site of the PAR1 receptor (NPNDKYEPF), the authors found the thrombin-binding sites to be 1800 sites per platelet $[14,15]$. Thus there appears to be a good agreement between the numbers reported in different studies, the differences may be a reflection of the different methods used.

The flow cytometric method used by us and by Dupont et al. [10] offers several advantages for the determination of platelet receptor numbers. It is fast and relatively simple, and it makes it possible to determine the number of several different receptors at the same time, as long as there is a mouse antibody targeting the receptor available and that the receptor number is high enough to be detectable and to be covered by the calibration curve. However, in our 
hands we have seen that the variation between duplicate samples may be considerable, especially in samples with low fluorescence intensities; therefore we do not recommend the use of single samples, as is proposed by the manufacturers.

The PAR1 receptor expression level has been reported to be associated with an intronic polymorphism, intervening sequence (IVSn)- 14A/T [10]. Individuals homozygous for the A allele also showed an increased response when activated by PAR1-AP [10, 12]. The genotyping of our population showed that the distribution of the A and $\mathrm{T}$ alleles were close to the one reported by Dupont et al. [10], who found 74\% A/A, 24\% A/T and 2\% T/T individuals in their French population. However, even though there seems to be a trend towards higher PAR1 receptor number and platelet reactivity in the A/A individuals in our study too, no statistically significant differences between A/A individuals and the T/A or T/T individuals were found. These findings lead to the conclusion that this polymorphism only explains a minor part of the individual variability in the number of PAR1 receptors observed in this study.

In contrast to the relatively strong correlation observed between mean platelet volume (MPV) and the number of the more abundant GPIb receptor, we only found a weak correlation between PAR1 receptor number and MPV, indicating that the platelet size is a comparably weak determinator of the number of PAR1 receptors. However, due to the individual variation in MPV, it is not fully correct to refer to the number of PAR1 receptors per platelet as "PAR1 density" (as commonly done) without measuring and correcting for individual differences in MPV. 
In this study we looked at the correlation between PAR1 receptor number and PAR1-APinduced fibrinogen binding and P-selectin exposure, using flow cytometry. We found a significant correlation between the PAR1 receptor density, on resting platelets, and either of the two markers of platelet activation. The correlations were similar to the ones reported by Dupont et al. who analysed platelets activated by PAR1-AP (SFLLRN) using aggregometry and P-selectin expression using flow cytometry [10]. However, our correlation between PAR1 receptor number and fibrinogen binding determined using flow cytometry is higher than the correlation reported by them using aggregometry, indicating that the flow cytometric approach to determine platelet fibrinogen receptor activation is more precise; a fact that is also supported by comparative studies [16]. A difference between the studies is that Dupont et al. [10] only used male donors. We therefore analysed our material for sex-related differences, but could not find any parameter that differed between male and female donors.

Despite the significant correlation between PAR1 receptor density and platelet activation found here and elsewhere [10], it is important to emphasise that other factors also affect the level of PAR1-mediated platelet activation. For example, Nylander et al. [17] achieved a 70\% platelet inhibition during thrombin activation by blocking the ADP receptor $\mathrm{P}_{2} \mathrm{Y}_{12}$ alone. Furthermore, an individual difference in the platelet content of dense granules, which contain ADP, both before and after platelet activation by PAR1-AP, have been found. This will therefore indirectly affect the level of platelet activation via the PAR1 receptor [18]. In addition, the number of $\mathrm{P} 2 \mathrm{Y}$ receptors per platelet and a range of other platelet agonists, such as adrenaline, collagen, lysophosphatidic acid, serotonin, thromboxane and platelet activating factor may also contribute to the PAR1-mediated platelet activation. Therefore we did a smaller study where we used ADP receptor antagonists to exclude the ADP component of the PAR1-AP induced response. However, this did not seem to improve the correlation between 
PAR1 receptor number and PAR1-AP induced activation response. To us, this was surprising, but the result highlights the fact that the relation between receptor activation and activation response is not easy to model and that many variables and unknown factors will affect the results.

To study the changes in PAR1 receptor number occurring after platelet activation, we activated platelets with PAR1-AP, PAR4-AP, ADP and a collagen related peptide (CRP). We found that the PAR1 receptor number decreased by approximately $30 \%$ upon activation with PAR1-AP, while activation with the other three agonists increased the number by $20-50 \%$. In accordance with our results, internalisation of PAR1 receptors has been reported to occur also after activation by PAR1-AP, even though this process does not involve any proteolytic cleavage of the receptor [8, 9]. Molino et al. [9] found a $60 \%$ decrease after activation with PAR1-AP (SFLLRN, $100 \mu \mathrm{M})$ or thrombin $(0.25 \mathrm{u} / \mathrm{mL})$ and a $40 \%$ increase with ADP (10 $\mu \mathrm{M})$ or $\mathrm{U} 46619$, a thromboxane $\mathrm{A}_{2}$ analogue $(10 \mu \mathrm{M})$, in a small number of samples $(\mathrm{n}=3)$. In addition, Dupont et al. [10] found a very small, but significant, decrease in PAR1 expression upon platelet activation by PAR1-AP (SFLLRN,100 $\mu \mathrm{M})$ or collagen $(100 \mu \mathrm{g} / \mathrm{mL})$ (the mean decrease in receptor numbers was just around 100) and no significant change after activation with $\mathrm{U} 46619(10 \mu \mathrm{M})$. Since Dupont et al. [10] did all their activation experiments in the presence of a fibrinogen receptor antagonist, we hypothesised that this might have had some influence on their results, but in our hands, the presence of a fibrinogen receptor antagonist did not change the results markedly, and our counting experiments also verified that the formation of platelet aggregates was low and did not influence our results. The decrease in receptor number after activation with collagen that was reported by Dupont et al. [10] was not seen in our study, instead activation by CRP markedly increased the PAR1 number, just like ADP and PAR4-AP, supporting the suggestion by Molino et al. [9] that 
PAR1 receptors originally present in the surface connecting system of the platelet plasma membrane become accessible upon activation of platelet receptors other than PAR1.

\section{Conclusion}

In conclusion, this study shows a large variation in PAR1 receptor number in healthy individuals, a variation that is correlated to the platelet activation response, although there are other factors likely to influence this interaction. The exclusion of the ADP-component of the PAR1-AP induced response did not improve the correlation between PAR1-receptor number and platelet activation response. Genotyping for the intervening sequence (IVSn)polymorphism 14A/T showed a trend, although there were no statistically significant differences in PAR1 receptor number and platelet reactivity between A/A individuals and T/A or T/T individuals. We found a significant reduction in PAR1 receptor surface exposure after adding PAR1-AP, while activation with ADP, PAR4-AP or CRP increased the surface exposure of PAR1 receptors.

\section{Acknowledgements}

This study was supported by the Swedish Research Council project K2007-64X-15060-04-3, the County Council of Östergötland and by the strategic research area "Inflammation, atherosclerosis and Ischemic heart disease-new strategies for prevention, diagnosis and treatment", which is sponsored by the County Council of Östergötland and the University of Linköping. The authors wish to thank all the blood donors and the staff of the Department of Clinical Chemistry, University Hospital, Linköping for their support. 


\section{References}

1. Klages B, Brandt U, Simon MI, Schultz G, and Offermanns S. Activation of G12/G13 results in shape change and Rho/Rho-kinase-mediated myosin light chain phosphorylation in mouse platelets. J Cell Biol 1999; 144: 745-54.

2. Vassallo RR, Jr., Kieber-Emmons T, Cichowski K, and Brass LF. Structure-function relationships in the activation of platelet thrombin receptors by receptor-derived peptides. J Biol Chem 1992; 267: 6081-5.

3. Xu WF, Andersen H, Whitmore TE, Presnell SR, Yee DP, Ching A, Gilbert T, Davie EW, and Foster DC. Cloning and characterization of human protease-activated receptor 4. Proc Natl Acad Sci U S A 1998; 95: 6642-6.

4. Vu TK, Wheaton VI, Hung DT, Charo I, and Coughlin SR. Domains specifying thrombin-receptor interaction. Nature 1991; 353: 674-7.

5. Vu TK, Hung DT, Wheaton VI, and Coughlin SR. Molecular cloning of a functional thrombin receptor reveals a novel proteolytic mechanism of receptor activation. Cell 1991; 64: 1057-68.

6. Faruqi TR, Weiss EJ, Shapiro MJ, Huang W, and Coughlin SR. Structure-function analysis of protease-activated receptor 4 tethered ligand peptides. Determinants of specificity and utility in assays of receptor function. J Biol Chem 2000; 275: 19728-34.

7. Kahn ML, Nakanishi-Matsui M, Shapiro MJ, Ishihara H, and Coughlin SR. Proteaseactivated receptors 1 and 4 mediate activation of human platelets by thrombin. J Clin Invest 1999; 103: 879-87.

8. Hoxie JA, Ahuja M, Belmonte E, Pizarro S, Parton R, and Brass LF. Internalization and recycling of activated thrombin receptors. J Biol Chem 1993; 268: 13756-63. 
9. Molino M, Bainton DF, Hoxie JA, Coughlin SR, and Brass LF. Thrombin receptors on human platelets. Initial localization and subsequent redistribution during platelet activation. J Biol Chem 1997; 272: 6011-7.

10. Dupont A, Fontana P, Bachelot-Loza C, Reny JL, Bieche I, Desvard F, Aiach M, and Gaussem P. An intronic polymorphism in the PAR-1 gene is associated with platelet receptor density and the response to SFLLRN. Blood 2003; 101: 1833-40.

11. Morton LF, Hargreaves PG, Farndale RW, Young RD, and Barnes MJ. Integrin alpha 2 beta 1-independent activation of platelets by simple collagen-like peptides: collagen tertiary (triple-helical) and quaternary (polymeric) structures are sufficient alone for alpha 2 beta 1-independent platelet reactivity. Biochem J 1995; 306: 337-44.

12. Smith SM, Judge HM, Peters G, Armstrong M, Dupont A, Gaussem P, and Storey RF. PAR-1 genotype influences platelet aggregation and procoagulant responses in patients with coronary artery disease prior to and during clopidogrel therapy. Platelets $2005 ; 16$ : $340-5$.

13. Harmon JT and Jamieson GA. Activation of platelets by alpha-thrombin is a receptormediated event. D-phenylalanyl-L-prolyl-L-arginine chloromethyl ketone-thrombin, but not $\mathrm{N}$ alpha-tosyl-L-lysine chloromethyl ketone-thrombin, binds to the high affinity thrombin receptor. J Biol Chem 1986; 261: 15928-33.

14. Brass LF, Vassallo RR, Jr., Belmonte E, Ahuja M, Cichowski K, and Hoxie JA. Structure and function of the human platelet thrombin receptor. Studies using monoclonal antibodies directed against a defined domain within the receptor $\mathrm{N}$ terminus. J Biol Chem 1992; 267: 13795-8.

15. Norton KJ, Scarborough RM, Kutok JL, Escobedo MA, Nannizzi L, and Coller BS. Immunologic analysis of the cloned platelet thrombin receptor activation mechanism: 
evidence supporting receptor cleavage, release of the $\mathrm{N}$-terminal peptide, and insertion of the tethered ligand into a protected environment. Blood 1993; 82: 2125-36.

16. Nylander S, Johansson K, Van Giezen JJ, and Lindahl TL. Evaluation of platelet function, a method comparison. Platelets 2006; 17: 49-55.

17. Nylander S, Mattsson C, Ramström S, and Lindahl TL. The relative importance of the ADP receptors, $\mathrm{P} 2 \mathrm{Y} 12$ and $\mathrm{P} 2 \mathrm{Y} 1$, in thrombin-induced platelet activation. Thromb Res 2003; 111: 65-73.

18. Ramström AS, Fagerberg I, and Lindahl T. A flow cytometric assay for the study of dense granule storage and release in human platelets. Platelets 1999; 10: 153-8. 


\section{Table legends:}

Table 1: Correlations between PAR1-receptor number and platelet activation in response to PAR1-AP (SFLLRN) in the absence and presence of the ADP-receptor antagonists MRS2179 $\left(\mathrm{P} 2 \mathrm{Y}_{1}\right)$ or cangrelor $\left(\mathrm{P} 2 \mathrm{Y}_{12}\right)$. Platelet activation was studied by flow cytometry detecting the binding of FITC-conjugated antibodies towards fibrinogen. Both the percentage fibrinogenbinding platelets and the mean fluorescence intensity from the platelet population were used for correlations. NS = not significant.

\section{Figure legends:}

Figure 1: Correlations between mean platelet volume and PAR1 receptor number (1A) and GPIb receptor number (1B).

Figure 2: Correlations between PAR1 receptor number and the percentage of platelets binding fibrinogen (2A) or exposing P-selectin (2B) after activation by PAR1-AP (SFLLRN).

Figure 3: Changes in PAR1 receptor number after platelet activation by PAR1-AP, ADP, PAR4-AP or a collagen related peptide. The bars show the mean and the error bars the standard deviation $(\mathrm{SD})$ in PAR1 receptor number. ${ }^{*}=\mathrm{p} \leq 0.05$ when compared to the sample with no activation from the same individual, $* *=p \leq 0.01$.

Figure 4: PAR1 receptor number in relation to genotype in the intervening sequence (IVSn)14. In the figure, every symbol represents one individual.

Figure 5: PAR1-AP-induced activation response in relation to genotype in the intervening sequence (IVSn)-14. Individuals were grouped into quartile groups 1-4 according to their 
fibrinogen binding in response to activation by PAR1-AP. The box plot shows the median, the $10^{\text {th }}, 25^{\text {th }}, 75^{\text {th }}$ and $90^{\text {th }}$ percentiles for the $\mathrm{A} / \mathrm{A}$ and $\mathrm{A} / \mathrm{T}$ individuals. The T/T individuals are represented by a dot for each individual. 
Table 1:

\begin{tabular}{|l|l|l|l|l|l|}
\hline $\begin{array}{l}\text { Platelet } \\
\text { activation/inhibition }\end{array}$ & $\mathrm{n}$ & $\begin{array}{l}\mathrm{r}^{2} \\
\% \text { positive platelets }\end{array}$ & Significance & $\begin{array}{l}\mathrm{r}^{2} \\
\text { MFI }\end{array}$ & Significance \\
\hline PAR1-AP $(75 \mu \mathrm{M})$ & 18 & 0.18 & $\mathrm{NS}$ & 0.10 & $\mathrm{NS}$ \\
\hline $\begin{array}{l}\text { PAR1-AP }(75 \mu \mathrm{M})+ \\
\text { MRS2179 }(20 \mu \mathrm{M})\end{array}$ & 18 & 0.24 & $\mathrm{p}<0.05$ & 0.12 & $\mathrm{NS}$ \\
\hline $\begin{array}{l}\text { PAR1-AP }(75 \mu \mathrm{M})+ \\
\text { cangrelor }(10 \mu \mathrm{M})\end{array}$ & 18 & 0.18 & $\mathrm{NS}$ & 0.0005 & $\mathrm{NS}$ \\
\hline $\begin{array}{l}\text { PAR1-AP }(75 \mu \mathrm{M})+ \\
\text { MRS2179 }(20 \mu \mathrm{M})+ \\
\text { cangrelor }(10 \mu \mathrm{M})\end{array}$ & 18 & 0.18 & NS & 0.02 & NS \\
\hline
\end{tabular}


Figure 1: 
$1 \mathrm{~A}$

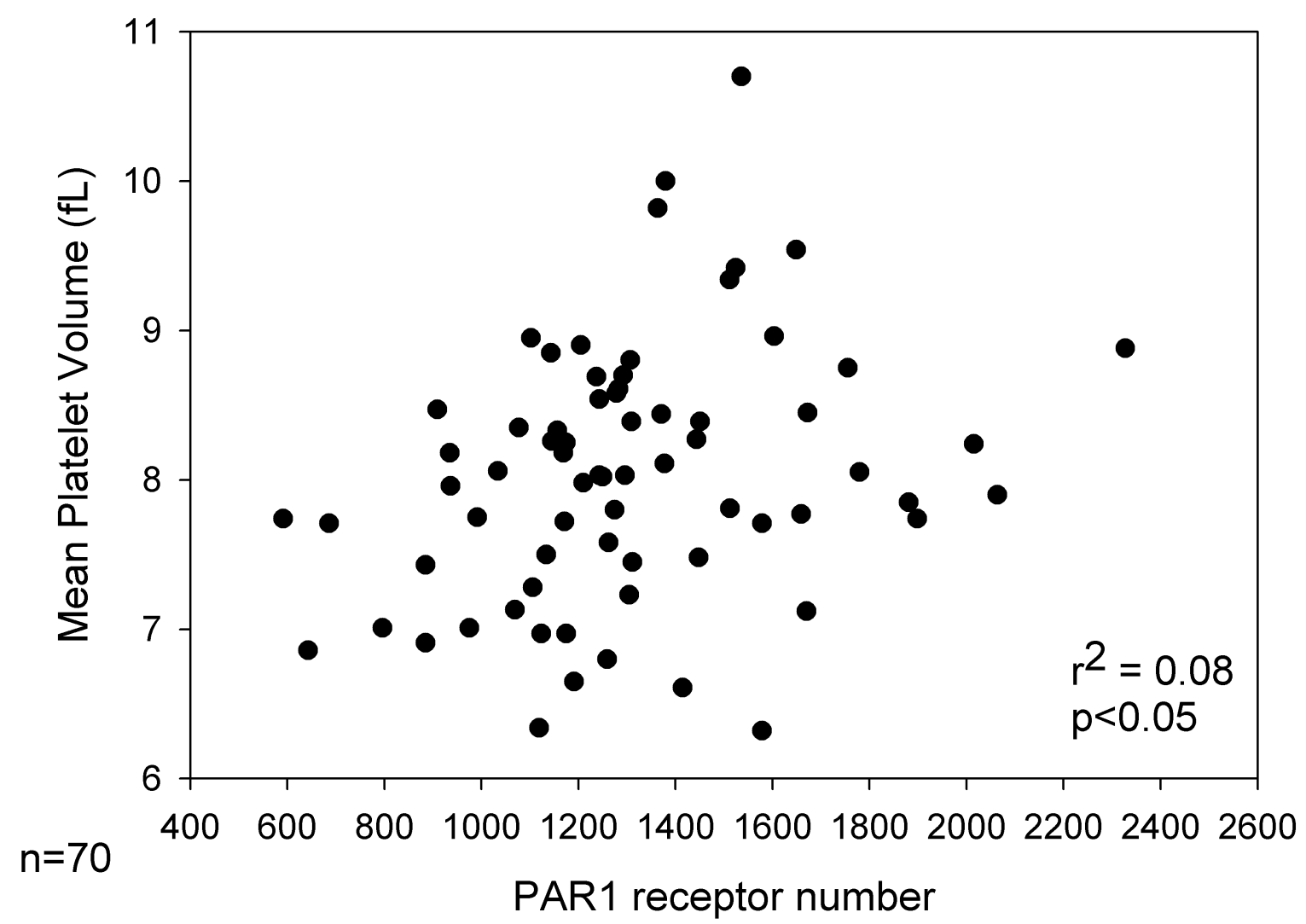

1B

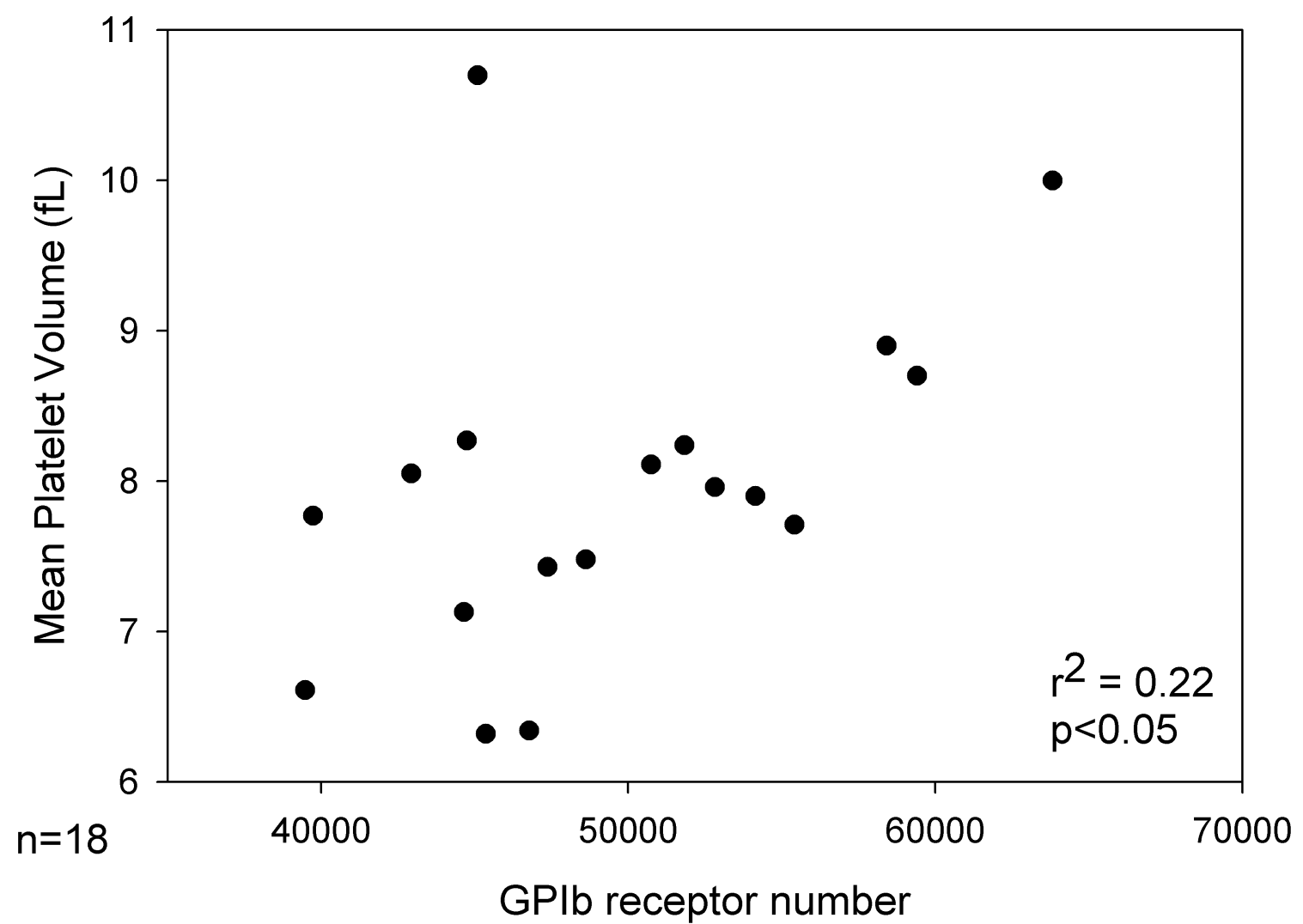


Figure 2: 
2A

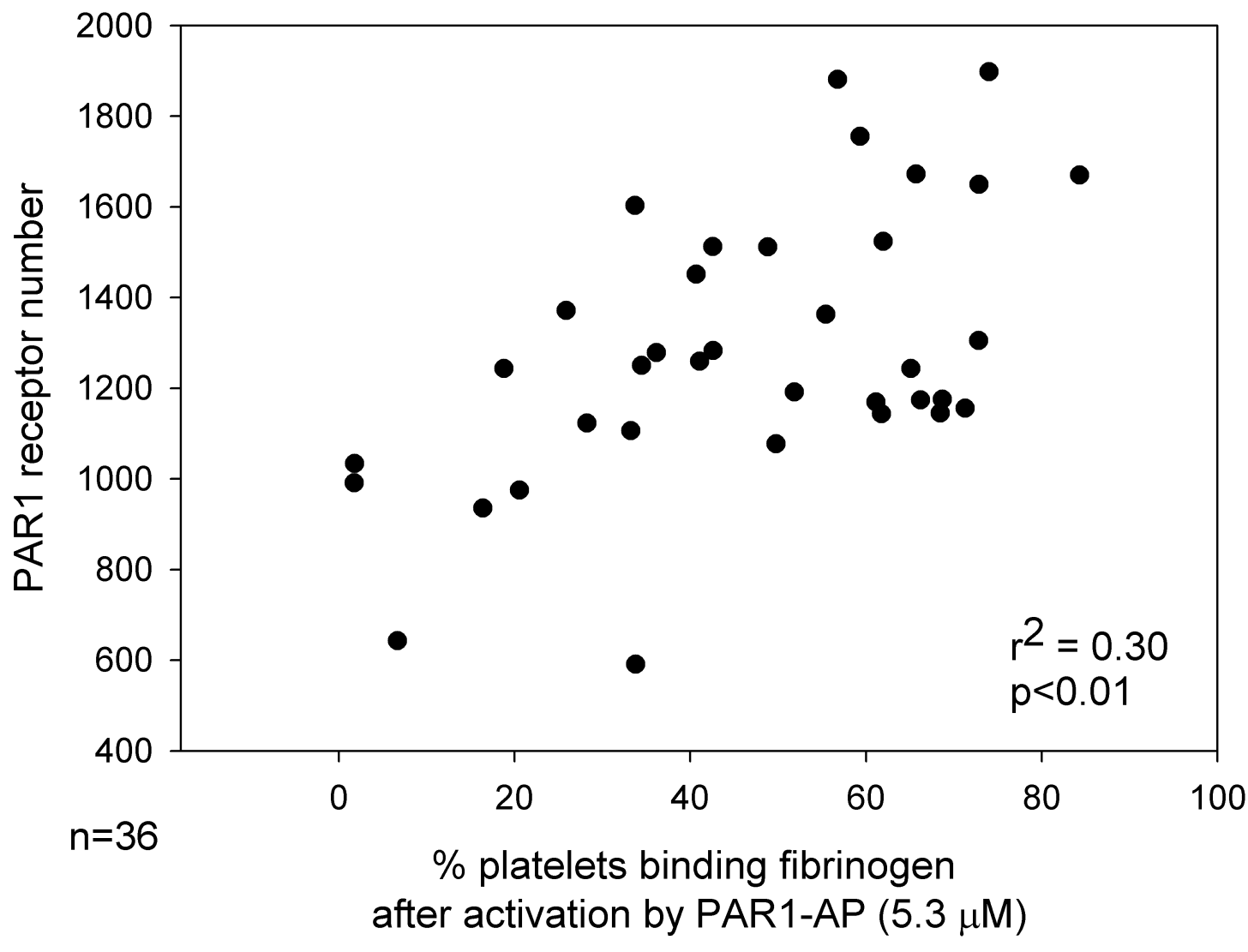

2B

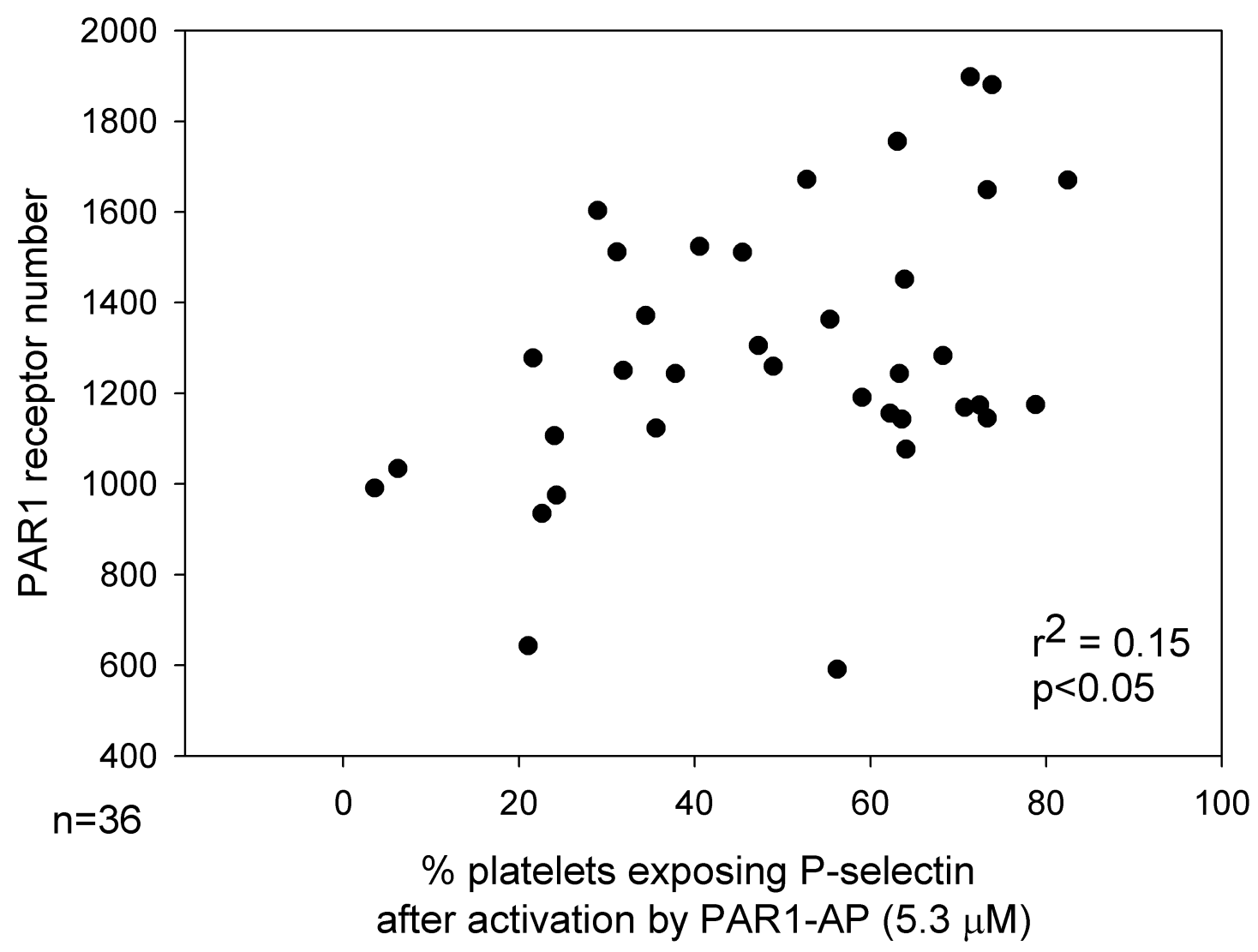


Figure 3:

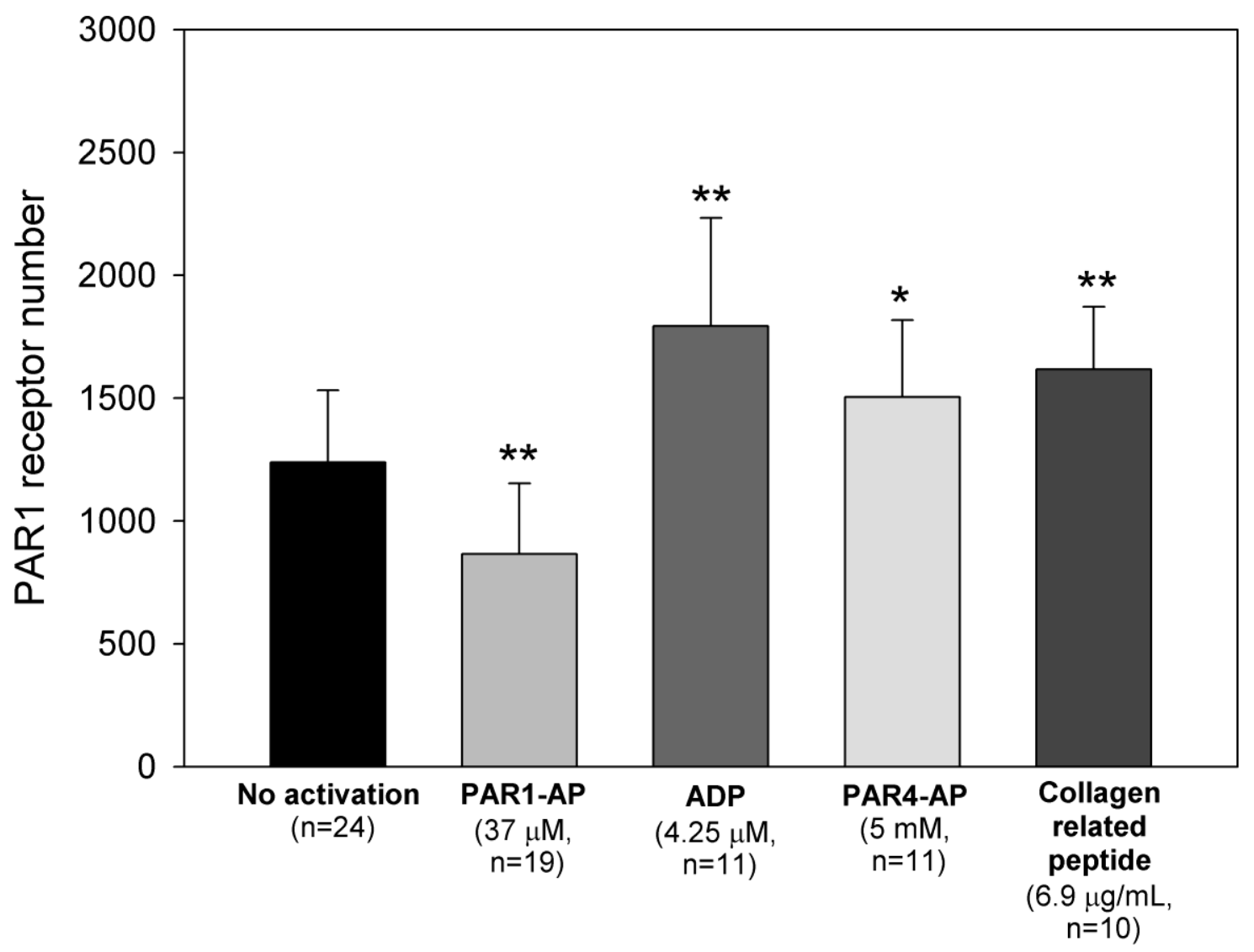


Figure 4:

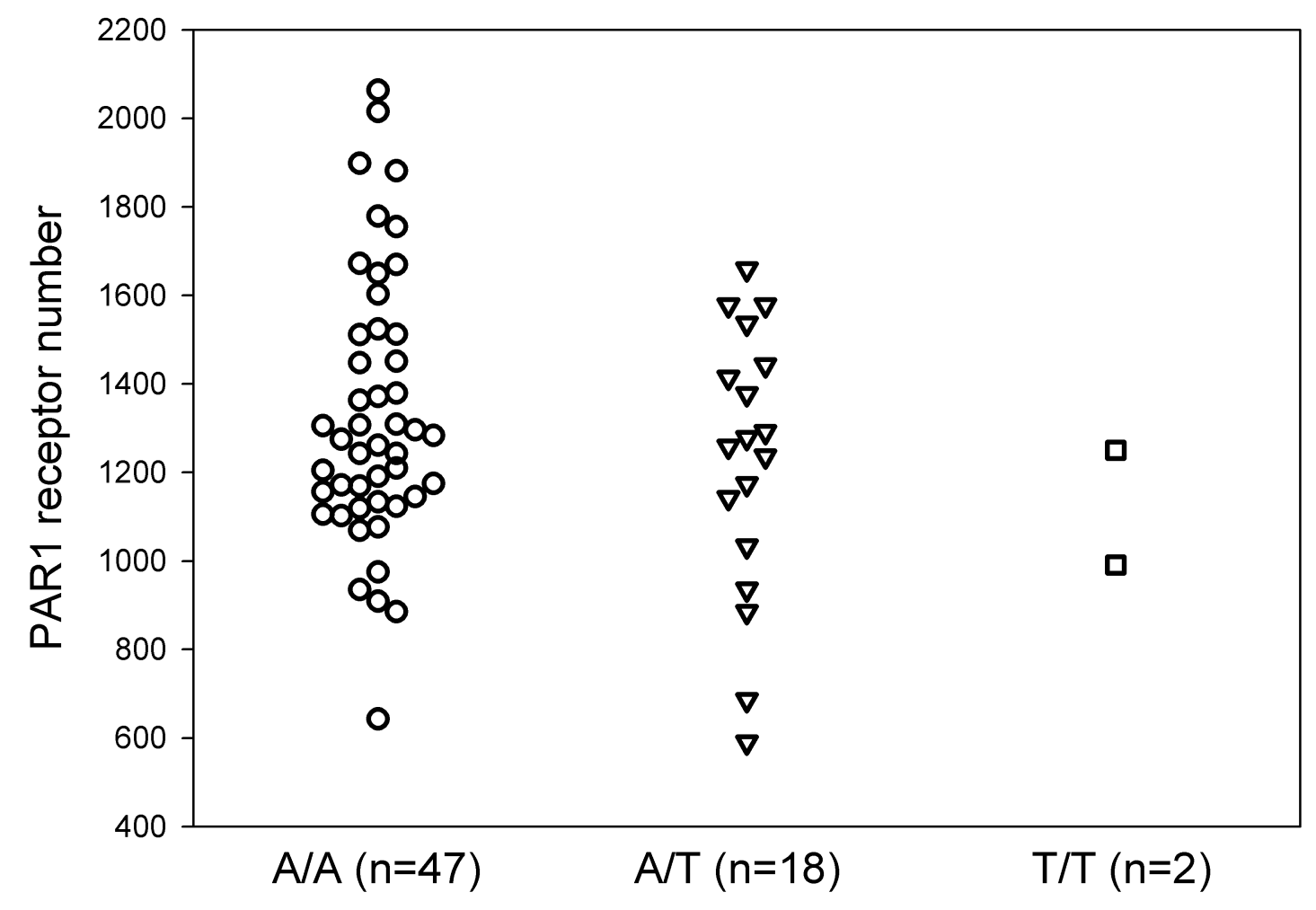


Figure 5:

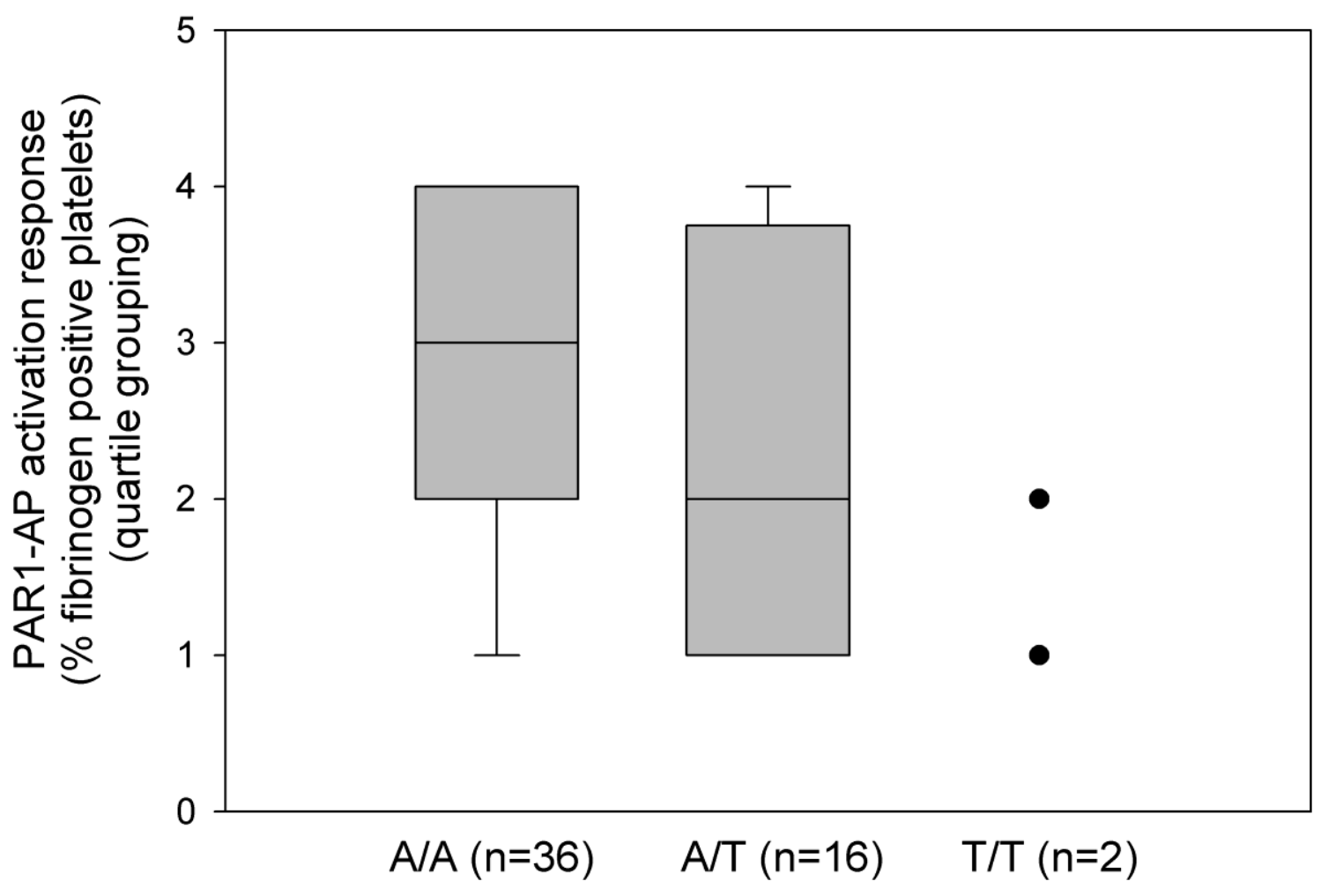

